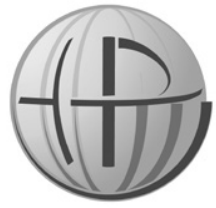

Horyzonty Polityki 2020, Vol. 11, No 35 OPEN ACCESS

\title{
Mirosław Lakomy
}

http://orcid.org/0000-0003-0556-1379 Akademia Ignatianum w Krakowie Instytut Nauk o Polityce i Administracji miroslaw.lakomy@ignatianum.edu.pl

Konrad OŚWIEcimski

http://orcid.org/0000-0002-0873-6827 Akademia Ignatianum w Krakowie Instytut Nauk o Polityce i Administracji konrad.oswiecimski@ignatianum.edu.pl

DOI: 10.35765/HP.1941

\section{Zjawisko zahibernowanej propagandy politycznej w nowych mediach}

\section{Streszczenie}

CEL NAUKOWY: Artykuł stawia sobie za cel zwrócenie uwagi na tlący się, poza głównym nurtem dyskursu publicznego, problem przyzwolenia dla propagandy goebbelsowskiej i akceptacji idei nazizmu. Problem ten zwłaszcza mocno nabrzmiewa w nowych mediach, a szczególnie wyraźnie można go zaobserwować na platformie YouTube, która stała się, dla środowisk neonazistowskich, przestrzenią agitacji politycznej.

PROBLEM I METODY BADAWCZE: Podstawową metodę badawczą stanowi analiza oraz interpretacja materiałów źródłowych w formie publikacji w serwisie YouTube. Obejmują one zarówno materiały propagandowe „wyprodukowane" pod kierownictwem Josepha Goebbelsa i "zahibernowane" we wspomnianym repozytorium, jak i komentarze oraz wtórne "produkcje” zwolenników tej ideologii. Praca obejmuje również analizę procesu amplifikacji propagandy w mediach społecznościowych w celu pokazania siły jej oddziaływania na pokolenie $\mathrm{Y}$ i Z.

PROCES WYWODU: Artykuł składa się z dwóch zasadniczych części. Pierwsza prezentuje kwestie historyczne związane z propagandą J. Goebbelsa oraz całym szeregiem produkcji medialnych służących mentalnemu podporządkowaniu społeczeństwa niemieckiego. Druga ukazuje zaś wpływ tych produkcji-zahibernowanych w mediach społecznościowych, a szczególnie w serwisie YouTube - na pokolenie $\mathrm{Y}$ oraz Z, które wychowały się w warunkach funkcjonowania powojennej demokracji.

Sugerowane cytowanie: Lakomy, M. i Oświecimski, K. (2020). Zjawisko zahibernowanej propagandy politycznej w nowych mediach. Horyzonty Polityki, 11(35), 105-123. DOI: 10.35765/HP.1941. 
WYNIKI ANALIZY NAUKOWEJ: Zasadniczym wnioskiem płynącym $\mathrm{z}$ analizy jest teza o silnym wpływie, zahibernowanej $w$ mediach społecznościowych, propagandy goebbelsowskiej oraz jej destruktywnym oddziaływaniu na pokolenia młodzieży w Europie. Jest to pierwszy tekst zwracający uwagę na ten bardzo niebezpieczny proces. Z przeprowadzonej analizy wynika, że poza głównym nurtem dyskursu publicznego tli się nurt rewanżystowski i neonazistowski, który stanowi zagrożenie dla ładu politycznego współczesnej Europy.

WNIOSKI, INNOWACJE, REKOMENDACJE: Ze względu na odniesienia historyczne do okresu lat trzydziestych i czterdziestych XX wieku artykuł może stać się podstawą refleksji nad współczesnymi kryzysami i zagrożeniami systemów demokratycznych, stanowiąc pewne ostrzeżenie przed nawrotem słusznie minionej epoki totalitaryzmów.

\section{SŁowA KLUCzowe:}

propaganda goebbelsowska, Leni Rieffenstahl, hibernacja propagandy, YouTube, neonazizm

\section{Abstract}

\section{HIBERNATED PROPAGANDA IN THE NEW MEDIA}

RESEARCH OBJECTIVE: The article aims to draw attention to the problem of the implicit consent to Göebbels propaganda and the acceptance of the idea of Nazism which takes place away from the mainstream public discourse but reaches pretty high levels. This problem is particularly visible in the new media and can be observed particularly clearly on the YouTube platform, which has become, for neo-Nazi circles, a place of political agitation.

THE RESEARCH PROBLEM AND METHODS: The basic research method for the article is the analysis and interpretation of source materials found on YouTube. These include propaganda materials "produced" under the direction of Joseph Goebbels and "hibernated" in this repository, as well as comments and secondary "productions" of supporters of this ideology. The work also includes an analysis of the process of amplifying propaganda in social media in order to show the strength of its impact on generations $\mathrm{Y}$ and $\mathrm{Z}$.

THE PROCESS OF ARGUMENTATION: The article consists of two essential parts. The first presents historical issues related to Joseph Goebbels' propaganda and a whole series of media productions for the mental subordination of German society. The second shows the impact of these productions, hibernated in social media and especially YouTube, on generation $Y$ and $Z$, which grew up in a post-war democracy. 
RESEARCH RESULTS: The main conclusion of the analysis is the thesis about the strong influence of Goebbels propaganda, hibernated in social media, and its destructive impact on generations of young people in Europe. This is the first text to draw attention to this very dangerous process. The analysis shows that beyond the main current of public discourse, there is a gradual rematch of the revanchist and neo-Nazi movements, which poses a threat to the political order of contemporary Europe.

CONCLUSIONS, INNOVATIONS AND RECOMMENDATIONS: Because of the historical references to the 1930s and 1940s, the article may serve as a basis for reflection on contemporary crises and threats to democratic systems, providing some warning against a return to a justly bygone era of totalitarianism.

\section{KeYwORDS:}

Goebbels propaganda, Leni Rieffenstahl, propaganda

hibernation, YouTube, neo-Nazism

\section{WSTĘP}

Idea podjęcia badania kategorii propagandy w postaci zahibernowanej, dostępnej w nowych mediach (szczególnie na platformie YouTube), narodziła się po analizie doniesień prasy niemieckiej na temat rosnącego zagrożenia o charakterze neonazistowskim. Już pobieżna obserwacja tego zjawiska dała nadzieję na dotarcie do znaczącego materiału źródłowego. W tych okolicznościach postawiono sobie za cel dokonać analizy sprofilowanej zawartości serwisu YouTube, przeszukując go według słów kluczowych odnoszących się do takich produktów propagandy III Rzeszy, jak: twórczość Leni Riefenstahl, kroniki filmowe „Die Deutsche Wochenschau” oraz filmy tematyczne odnoszące się do Waffen SS. Analiza całościowa materiałów propagandowych, które powstały w latach 1933-1945 pod kierownictwem Goebbelsa, była niemożliwa do zrealizowania w warunkach niniejszego artykułu, dlatego zakres pracy ograniczono do wspomnianych wyżej materiałów. Posłużono się metodą analizy zawartości oraz analizą procesu amplifikacji w mediach społecznościowych (Płuciennik, 2013) dla zaakcentowania siły oddziaływania tej propagandy na pokolenie Y i Z. Teza pracy zasadza się na przypuszczeniu, że produkty propagandy nazistowskiej, opublikowane w postaci cyfrowej w serwisie YouTube, są konsumowane przez środowiska neonazistów oraz 
podlegają amplifikacji w mediach społecznościowych, stanowiąc potencjalne zagrożenie dla obecnego ładu społecznego i politycznego w Europie. Trzeba jednocześnie mocno podkreślić, że władze Niemiec systematycznie monitorują oraz zwalczają te środowiska, mając w pamięci historię II wojny światowej oraz wydarzenia znane jako tzw. pucz monachijski, którego 100. rocznica przypada w 2023 roku. Praca ma charakter politologiczno-medioznawczy.

\section{O ISTOCIE I ŹRÓDŁACH PROPAGANDY JOSEPHA GOEBBELSA}

Joseph Goebbels, kluczowa postać propagandy nazistowskiej w okresie III Rzeszy, był doskonale przygotowany merytorycznie do dyrygowania działalnością propagandową. Doktorat z literaturoznawstwa obronił w 1922 roku w Uniwersytecie Ruprechta i Karola w Heidelbergu. Już dwa lata później związał się z nielegalnym wówczas ruchem NSDAP. Pełnił tam funkcję dziennikarza i publicysty. Był zafascynowany Adolfem Hitlerem, w którym dostrzegał charyzmę człowieka, który „przywróci Niemcom wiarę” (Longerich, 2015). Przypomnieć należy kontekst tej wypowiedzi odnoszący się do przegranej I wojny światowej oraz upokarzających warunków kapitulacji, strat terytorialnych i wysokich reparacji wojennych. Kiedy Hitler został wypuszczony z więzienia, działalność narodowych socjalistów nabrała rozpędu. J. Goebbels, już jako znaczący członek ugrupowania, podjął się wygłaszania płomiennych przemówień na wiecach oraz przygotowywania ulotek i artykułów propagandowych dla prasy. W 1930 roku objął funkcję głównego propagandysty NSDAP. Dla zwiększenia zasięgu oddziaływania partii na odbiorców wykorzystał jej czasopismo „Der Angriff” (Lemmons, 2015), gdzie agitował przeciwko ustrojowi politycznemu Republiki Weimarskiej oraz podsycał antysemityzm. Gazeta znacząco zwiększyła w tym czasie nakład (z dwóch do niemal stu pięćdziesięciu tysięcy egzemplarzy) oraz częstotliwość ( $\mathrm{z}$ dwóch razy w tygodniu do dwóch razy dziennie). Po przejęciu władzy przez Nazistów (Machtergreifung) ${ }^{1}$, Goebbels

1 Machtergreifung - przejęcie, sięgnięcie po - termin ten oznacza w literaturze niemieckiej przejęcie władzy przez NSDAP 30 stycznia 1933 roku, w wyniku 
jako minister propagandy i oświecenia publicznego (wyraźnie widać tutaj echa teorii hegemonii Gramsciego) przystąpił do likwidacjitytułów prasowych, które uznał za wrogie. „Uszczelnił” wszystkie kanały informacyjne, za pomocą których (szczególną rolę odegrało tutaj radio, tzw. Volksempfänger) (Aylett, 2008) docierał z treściami propagandowymi do odbiorców. W 1939 roku postanowił wykorzystać także film dokumentalny do kształtowania postaw Niemców. W tym celu połączył cztery istniejące kroniki filmowe - „Ufa-Tonwoche”, „Deulig-Tonwoche”, „Tobis-Woche”, „Fox-Tönende Wochenschau” w jedną - „Die Dutsche Wochenschau”. Jak twierdzi Stephen Halbrook:

każdy odcinek kroniki był przeglądany przez Josepha Goebbelsa, a następnie przekazywany do osobistej akceptacji Adolfa Hitlera. Oznaczało to oczywiście cenzurę oraz absurdalną centralizację kontroli nad publikowanymi treściami. Typowy odcinek przedstawiał zwykle licznych - zabitych lub oddających się do niewoli - żołnierzy wroga, podczas gdy uśmiechnięci żołnierze Wehrmachtu wyglądali na zadowolonych i wypoczętych. Nigdy, nawet po Stalingradzie, nie pokazywano ciał zabitych Niemców ani też niczego, co mogłoby kojarzyć się z nadchodzącą klęską. Ujęciom pikujących niemieckich bombowców niezmiennie towarzyszył przeraźliwy dźwięk wyjących syren, po których następował odgłos eksplozji spadających bomb (Halbrook, 2015, 61-64).

$\mathrm{Z}$ pomocą tak konstruowanych treści budował $\mathrm{w}$ narodzie niemieckim poczucie dumy i siły, u wrogów zaś poczucie strachu, lęku oraz beznadziejności w obliczu niemieckiej potęgi. W tym kontekście pojawia się pytanie o to, skąd u Goebbelsa tak specjalistyczna wiedza i zdolności do konstruowania niezwykle skutecznej propagandy. Próbując odpowiedzieć na to pytanie, należy zwrócić uwagę na kilka elementów.

demokratycznych wyborów i przeobrażenie tego ustroju w dyktaturę totalitarną. Dokonano tego dzięki uchwaleniu przez Reichstag 23 marca tego roku ustawy o pełnomocnictwach (Ermächtigungsgesetz), nadającej gabinetowi prawo wydawania ustaw rządowych, co zapoczątkowało transformację ustrojową w Niemczech. Proces ten przeszedł do historii jako model przekształcania demokracji, za pomocą demokratycznych procedur, w ustrój niedemokratyczny (totalitarny). W 1937 roku Karl Loewenstein opublikował dzieło odnoszące się do tego zjawiska, nazywając ten proces militant democracy. 
W działaniach propagandowych posługiwano się do tej pory dorobkiem tzw. psychologów zbiorowości, m.in. Gustawa Le Bona czy Wilfrieda Trottera. Ważną rolę odegrała też teoria warunkowania (tzw. odruchy warunkowe opisane pierwotnie przez Iwana Pawłowa), rozwinięta później przez behawiorystów (np. warunkowanie instrumentalne Burrhusa Frederica Skinnera). Technika ta polega na uporczywym, wielokrotnym powtarzaniu określonych treści ideologicznych, które kojarzono z kolei z tzw. popędami (znaczny wkład w rozwój psychoanalizy włożył z kolei Zygmunt Freud) ${ }^{2}$. Sztuka propagandy opierać się miała, zdaniem Siergieja Chakhotina, na umiejętności wykorzystywania tych naturalnych popędów do sterowania ludźmi. Jego model, stworzony w 1939 roku na podstawie obserwacji działań reżimu hitlerowskiego, uwypuklał:

zależność efektu propagandy od umiejętnego zestrojenia z popędami człowieka, w pewnym sensie powtarzał myśl Platona, że retoryka sztuka przekonywania - jest w rzeczywistości sztuką pochlebstwa, gdyż na tyle tylko osiagga rezultaty perswazyjne na ile potrafi schlebiać słuchaczom. (...) Została ona opracowana na bazie medialnej propagandy wojennej. Nadawcy, używając ukierunkowanych treści (haseł, sloganów), w sposób ciągły i systematyczny pobudzają wewnętrzne motywy zachowania (popędy, instynkty ${ }^{3}$ ) odbiorców na zasadzie relacji bodziec - reakcja. Model ten zakłada bierność i irracjonalizm zachowań jednostki oraz dużą jej uległość na treści propagandowe (Model wszechmocy propagandy, 2016).

Teorię propagandy Siergieja Chakhotina uznano za kwintesencję mechanistycznych możliwości manipulowania opinią publiczną.

2 Zgodnie z nauką Freuda istnieją dwie podstawowe kategorie popędów: popędy życia i popędy śmierci. Popędy życia służyć mają przetrwaniu i przedłużeniu gatunku (libido). Popędy śmierci natomiast mają destrukcyjny charakter i są związane z agresją. Oba zmuszają człowieka do aktywności.

3 Instynkt (łac. instinctus - podnieta, popęd). Istnieją trzy podstawowe instynkty: instynkt samozachowawczy i przetrwania, seksualny (przedłużenie rodu) oraz instynkt lidera. Instynkty człowieka powodują powstanie potrzeb: dobra materialne, dążenie do bezpieczeństwa, poszukiwanie partnera seksualnego, dbanie o dzieci, potrzeba wpływania na otaczających ludzi. Człowiek ma także inne instynkty naturalne, takie jak: instynkt macierzyński, instynkt bronienia własnego terytorium, instynkt naśladowania. W odróżnieniu od zwierząt możemy kontrolować własne instynkty za pomocą rozumu i ducha (instynkty człowieka). 
Zjawisko zahibernowanej propagandy politycznej w nowych mediach

Przeszła ona do historii komunikologii jako teoria magicznego pocisku (magic bullet theory) lub zastrzyku podskórnego. Jej istotą jest twierdzenie o

całkowitej pasywności odbiorcy i jego braku odporności na przekaz. Przekaz bowiem jest jak pocisk, który jeśli ugodzi w konkretną publiczność, zawsze wywoła zamierzony efekt w postaci konkretnej reakcji identycznej dla wszystkich odbiorców (Model wszechmocy propagandy, 2016).

W jego koncepcji propagandy w Europie, opartej na behawiorystycznych teoriach społeczeństwa masowego, odnajdujemy także związki z metodologią urabiania opinii publicznej w Stanach Zjednoczonych wypracowaną przez zespół George’a Creela, którego członkiem był także Edward Bernays. Nie bez powodu wspominamy działania Komitetu Creela, działającego od 1917 do 1919 roku. Stały się one bowiem inspiracją dla propagandy nazistowskiej realizowanej w III Rzeszy. Jak się dowiadujemy, jeszcze w latach dwudziestych XX wieku Joseph Goebbels stał się zapalonym wielbicielem twórczości Edwarda Bernaysa. Kiedy został ministrem propagandy III Rzeszy, postanowił wykorzystać jego dorobek. Informację o tym fakcie Bernays otrzymał od Karla von Wieganda, reportera amerykańskiej gazety „Hearst Corporation”. Dziennikarz miał okazję spotkać się Goebbelsem i przeprowadzić z nim wywiad, w jego doskonale zaopatrzonej bibliotece. Można w niej było odnaleźć - jak twierdził także dzieła czołowych psychologów społecznych, wśród których twórca Public Relations i autor Propagandy zajmował główną pozycję. Bernays skomentował tę informację dopiero w wydanej w roku 1965 autobiografii i brzmiało to następująco:

Ja wiedziałem, że każdą ludzką aktywność można zastosować dla dobra większości lub nadużyć w celach antyspołecznych. Jak się okazało, atak przeciwko Żydom w Niemczech nie był spowodowany emocjonalnym wybuchem nazistów tylko był zaplanowana, dobrze przemyślaną kampanią (Tye, 1998, 111).

Znając zatem źródła i mechanizmy propagandy nazistowskiej, funkcjonującej w okresie III Rzeszy, wiemy dlaczego ówczesna opinia publiczna tak łatwo poddawała się perswazji i manipulacji realizowanej przez ten reżim. Kulminacją owego silnego wpływu 
było przemówienie ministra Josepha Goebbelsa w Berlinie 18 lutego 1943 roku, w którym wzywa naród niemiecki do wojny totalnej. Sala w Pałacu Sportu została wypełniona starannie dobraną publicznością cechującą się ponadstandardową gorliwością i wiarą w Rzeszę Niemiecką. Po owym evencie "Goebbels powiedział Albertowi Speerowi, że była to najlepiej wytrenowana publiczność, jaką można było znaleźć w Niemczech" (German Propaganda Archive, 1998). Przemówienie to od 18 lutego 2014 roku dostępne było w wersji oryginalnej, z brytyjskim komentarzem w serwisie YouTube (około 15 tysięcy wyświetleń w 2019 r.) $)^{4}$.

\section{ZAHIBERNOWANA PROPAGANDA W SERWISIE YOUTUBE}

Serwis YouTube (YT) jest serwisem typu DIY (Do It Yourself). Oznacza to, że wszystkie filmy, stanowiące kontent serwisu, są zamieszczane tam przez użytkowników na zasadzie prosumpcji. Kiedy w 2005 roku, trzej koledzy - Jawed Karim, Steve Chen, Chad Hurley - zdecydowali się utworzyć taki serwis, opierali swoją decyzję na obserwacji zachowań ludzi, którzy bardzo często rejestrowali różne sceny ze swojego życia za pomoca prywatnych kamer analogowych, a więc na taśmie magnetycznej. Mocno zakorzeniona potrzeba utrwalania rzeczywistości i ulotności życia sprawiła, że YT odniósł sukces i dzisiaj cieszy się popularnością największego repozytorium plików wideo na świecie. Początki jego funkcjonowania miały charakter amatorski, $\mathrm{z}$ czasem serwis przekształcił się $\mathrm{w}$ portal o charakterze mieszanym, z rosnącym udziałem komponentu biznesowego. Działalność ta rozwija się szczególnie dynamicznie od momentu aliansu z korporacją Google. Jak wynika z danych dostępnych na stronie informacyjnej YT,

ponad 1,9 miliarda zalogowanych użytkowników odwiedza YT co miesiąc, a widzowie oglądają codziennie ponad miliard godzin filmów i generują miliardy wyświetleń. Ponad 70\% czasu oglądania w YouTube jest generowane przez urządzenia mobilne. YouTube ma swoje wersje

4 Film obecnie niedostępny. W 2019 roku znajdował się pod adresem: https:// www.youtube.com/watch?v=losEBtmq68. 
lokalne w ponad 91 krajach. Dostępny jest w 80 językach, co obejmuje 95\% wszystkich użytkowników Internetu (YouTube dla prasy).

Ma zatem ogromny zasięg geograficzny i społeczny, dzięki czemu stanowi pożądane medium zarówno przez przedsiębiorców (w celach marketingu biznesowego), jak i polityków (marketing polityczny i PR) oraz różnego rodzaju aktywistów i działaczy społecznych. Liczba zamieszczanych w serwisie filmów jest niepoliczalna, ulega bowiem dynamicznym zmianom. Dotarcie do określonego materiału jest możliwe dzięki wewnętrznej wyszukiwarce, która dostarcza użytkownikowi propozycje filmów zbliżonych treścią do słów kluczowych użytych do wyszukiwania. Zatem odnalezienie interesujących nas filmów jest stosunkowo łatwe.

Przy tej okazji należy wspomnieć o przyczynach, dla których treści historycznej propagandy hitlerowskiej są udostępniane w sieci. Otóż władze Republiki Federalnej Niemiec zdecydowały, że całe dziedzictwo kulturowe z okresu nazistowskiego należy wyłączyć z ochrony prawno-autorskiej i można z niego korzystać w domenie publicznej. W okresie poprzedzającym rewolucję cyfrową zasoby te były dostępne dla ograniczonej grupy badaczy w ramach dociekań historycznych, filmoznawczych czy komunikologicznych (propaganda) z pomocą wyspecjalizowanych instytucji archiwistycznych. Korzystanie z nich było utrudnione ze względu na archaiczną technologię zapisu na podłożu nitrocelulozowym. Dopiero kapitałochłonny proces digitalizacji tych zbiorów umożliwił ich zamieszczenie w różnych repozytoriach, w tym głównie na platformie YouTube. Pierwotnym celem tych działań było przeznaczenie ich jako materiały poglądowe wykorzystywane w szeroko rozumianej edukacji (prewencja).

Od kilkunastu więc lat w serwisie znajdują się materiały wykorzystujące filmy propagandowe produkowane w okresie III Rzeszy przez podwładnych Josepha Goebbelsa. Zwykle są one opatrzone profesjonalnym, współczesnym komentarzem historycznym, z którego jednoznacznie wynika, że reżim ten miał charakter zbrodniczy i należy go potępiać. Jednakże praktyka ostatnich kilku lat pokazuje, iż coraz więcej prywatnych kanałów zamieszcza zdigitalizowane materiały propagandowe nazistów $w$ formie pierwotnej, dając w ten sposób widzom możliwość dokonywania własnych ocen, jednocześnie nie łamiąc prawa. Materiały te mają potencjał, aby oddziaływać na 
widzów w podobny sposób, w jaki oddziaływały one w latach trzydziestych i czterdziestych $X X$ wieku w Niemczech. $Z$ tą różnica, że dzisiaj ich zasięg geograficzny i społeczny jest globalny, w związku z tym można przypuszczać, iż poziom dewastacji systemów wartości pokolenia Y może być znacznie większy niż pokolenia WWII (drugiej wojny światowej). Dostrzegamy w wielu środowiskach zmianę kursu dyskusji i akceptację, a nawet przyzwolenie dla działań podejmowanych wówczas przez nazistów. Można więc postawić tezę, że narracja propagandowa budowana przez zespół kierowany przez J. Goebbelsa przetrwała w formie zahibernowanej i dzisiaj, po ucyfrowieniu i zamieszczeniu w serwisie YouTube nabiera pierwotnego charakteru. Ponownie silnie kształtuje postawy innego już pokolenia odbiorców. Jak można się o tym przekonać? Otóż serwisy społecznościowe mają to do siebie, że umożliwiają użytkownikom wchodzenie w interakcje. W YouTube jest to możliwe dzięki usłudze komentarze, gdzie widzowie po wyświetleniu filmu mogą zapisywać swoje opinie, udostępniać obejrzany materiał, lajkować go, a także zapraszać do oglądania zawartości własnego kanału.

W celu weryfikacji tezy o oddziaływaniu zahibernowanej propagandy nazistowskiej na odbiorców serwisu YT dokonano analizy komentarzy umieszczonych pod wybranymi materiałami propagandowymi w wersji oryginalnej. Szczególna, pogłębioną analizę przeprowadzono w odniesieniu do autorów tych komentarzy, którzy „ulegli urokowi” narracji nazistowskiej. W ten sposób, śledząc ich linki, odkryto wiele swego rodzaju neoplemion, wyodrębnionych spośród użytkowników YT, charakteryzujących się szczególnie przychylną opinią o okresie III Rzeszy. Wybrane do badania filmy to produkcje Leni Riefenstahl, niektóre kroniki filmowe oraz materiały na temat zbrodniczej organizacji Waffen SS.

\section{ANALIZA WYBRANYCH PRZYKŁADÓW \\ ZAHIBERNOWANEJ PROPAGANDY NAZISTOWSKIEJ W SERWISIE YOUTUBE}

Leni Riefenstahl, uważana powszechnie za reżyserkę Adolfa Hitlera, po wysłuchaniu jego przemówienia na wiecu NSDAP w 1932 roku, doznała pewnych irracjonalnych emocji, które moglibyśmy 
Zjawisko zahibernowanej propagandy politycznej w nowych mediach

zakwalifikować zgodnie z freudyzmem jako instynktowne. Jak przytacza Taylor Downing (2012) w swoim pamiętniku napisała:

miałam niemal apokaliptyczną wizję, której nigdy nie mogłam zapomnieć. Wydawało się, że powierzchnia Ziemi rozpościera się przede mną jak półkula, która nagle rozpada się na środku wyrzucając ogromny strumień wody, tak potężny, że dotknął nieba i wstrząsnął ziemią.

Od tej chwili całkowicie oddała swój talent do dyspozycji partii nazistowskiej. Na polecenie Goebbelsa wyreżyserowała następujące filmy: w 1932 roku - Das Blaue Licht (The Blue Light) w 1933 - Der Sieg des Glaubens (The Victory of Faith) w 1935 - Triumph des Willens (Triumph of the Will - Triumf Woli), w 1935 - Tag der Freiheit: Unsere Wehrmacht (Day of Freedom: Our Armed Forces) w 1937 - Wilde Wasser (Wild Water) i w 1938: Olympia. Zdaniem badaczy jej dorobku najważniejszą produkcją był film pt. Triumf Woli z 1935 roku. Jest on obecny zarówno w serwisie YouTube, jak i Vimeo oraz Dailymotion. $\mathrm{W}$ serwisie YT film ten dostępny jest w wielu wersjach językowych, ale jednocześnie czasowo okrojony do zaledwie kilku minut i opatrzony odpowiednim komentarzem. Zdaniem badaczy propagandy nazistowskiej film ten bardzo mocno wpływa na emocjonalność wi$\mathrm{dza}$, stąd być może obawa przed publikacją całej wersji w oryginale. Ponadto główną rolę reżyserka oddała tutaj Hitlerowi, który zasłynął z niezwykle dynamicznych przemówień. Produkcja ta wykreowała kult przywództwa Führera w III Rzeszy. Liczba wyświetleń, lajków oraz dostępne komentarze nie wzbudzają obaw zwerbalizowanych na wstępie artykułu. Podobny wniosek można sformułować po obejrzeniu pozostałych filmów Leni Riefenstahl w YT. Skłania to do odrzucenia jednej z tez sformułowanych na wstępie. Oznacza to, że wokół tych produkcji nie tworzą się neonazistowskie neoplemiona albo są one blokowane przez serwis. Można też założyć, że stylistyka filmów Riefenstahl nie trafia w gusta współczesnego odbiorcy.

Jeśli chodzi o kroniki filmowe, o których wspomniano wyżej, to należy stwierdzić, iż z zamieszczanych do nich komentarzy wyłaniają się zgoła inne wnioski. Spróbujmy zatem poddać analizie kilka, losowo wybranych filmów dostępnych w YT.

Jednym z nich jest kronika „Die Deutsche Wochenschau”. Film dostępny jest na kanale YT (Die Deutsche Wochenschau) od 18 stycznia 
2018 roku. Na dzień badania miał 6015 wyświetleń i 43 polubienia. Ponadto możemy odczytać trzy komentarze, z których d wa potwierdzają postawioną na wstępie tezę. Pierwszy z nich, zamieszczony przez osobę o inicjałach HS, jest krótki, ale wyraża nostalgię za czasami nazizmu i budzi obawy: „Stare, dobre czasy!” (niem. Die gute alte Zeit!). Wejście na kanał autora tego krótkiego postu to jakby przejście na drugą stronę lustra. Otwiera się tam świat wyznawców słusznie minionej ideologii, którzy utwierdzają się w przekonaniu co do jej słuszności (tkwią w neonazistowskiej komorze pogłosowej). Możemy stąd przedostać się do następujących kanałów kontestujących obecny ład polityczny w Europie dzięki zamieszczaniu tamże filmów o nostalgicznym charakterze. Spróbujmy je prześledzić. Pierwszy to: Freies Schlesien z 3750 subskrypcjami (Freies Schlesien). Nadawca proponuje do obejrzenia m.in. następujące tytuły: Das Alte Breslau (74 285 wyświetleń), Die Kattowitzer Polka (1600 wyświetleń), 1918-2018 In Gedenken und Würdigung unserer Gefallenen (1136 wyświetleń). W ostatnim filmie widać mężczyzn ubranych w jednakowe bluzy w kolorze czarnym z napisem na plecach: Oberschlesien (Górny Ślask), którzy odwiedzają cmentarze niemieckie na ziemiach polskich. Użytkownik o inicjałach DS napisał w komentarzu:

Dzięki! Nie możemy zapominać, że Katowice w referendum w 1921 roku zagłosowały $85,4 \%$ do Niemiec! Do serca dołączam wszystkie poniższe, bardzo interesujące filmy na YouTube: Górny Śląsk - Niezapomniany dom na Wschodzie ${ }^{5}$.

Zastanowienie wzbudza także wpis pod Nickiem: Reconquista Germanica z 18.04.2015 roku:

Na Dolnym Śląsku niemieckie cmentarze były i są nie tylko zaniedbywane, ale nawet celowo zbezczeszczone. Prasa i klasa polityczna utrzymują ten stan $\mathrm{w}$ tajemnicy $\mathrm{w}$ obliczu bezgranicznej podłości wobec narodu niemieckiego - ale nie można się zbyt wiele spodziewać z powodu wykorzenienia. Państwo polskie, nic nie robi w tych

5 W oryginale: „Danke! Wir dürfen auch nicht vergessen, dass sich Kattowitz in der Volksabstimmung des Jahres 1921 mit 85,4\% zu Deutschland bekannte! Ich lege allen einmal das folgende, sehr sehenswerte Video hier auf Youtube dazu ans Herz: „,Oberschlesien - Unvergessene Heimat im Osten”. 
warunkach. Druzgocące świadectwo opuszczonego stanu, w którym znajdują się Niemcy ${ }^{6}$.

Z kolei film pt. Oberschlesien - Unvergessene Heimat im Osten (Górny Śląsk - Niezapomniany dom na wschodzie) przywołał m.in. następujące komentarze: „Oberschlesien ist mein liebes Heimatland (Górny Śląsk jest moją ukochaną ojczyzną); „Freiheit für Schlesien, Allen oberschlesischen Landsleuten lege ich das folgende Youtube-Video hier ans Herz: „Die Oberschlesier - Tatsachen über Oberschlesien” (Wolność dla Śląska, polecam wszystkim rodakom z Górnego Śląska następujący film na YouTube: „Die Oberschlesier - Tatsachen über Oberschlesien”); „ein schönes Lied, meines Vaters Heimatland" (Piękna piosenka, ojczyzna mojego ojca).

Przywołany w komentarzu film Die Oberschlesier - Tatsachen über Oberschlesien (Górny Ślask - Fakty o Górnym Ślasku) został skomentowany przez użytkownika o inicjałach MG następująco: „Ich bin Deutscher und Schlesier. Ich kann auf deutsch und aud polnisch sprechen aber meine Vaterland ist Deutschland und Heimatland Schlesien" (Jestem Niemcem i Ślązakiem. Potrafię mówić po niemiecku i po polsku, ale moją ojczyzną są Niemcy, a moja ziemia ojczysta to Śląsk).

Na tym kanale polecane są inne, "modne” (niem. angesagte) kanały. Wśród nich odnajdujemy: Freies Pommern (Wolne Pomorze, 798 subskrypcji) - (Freies Pommern), Freies Ostpreussen (Wolne Prusy Wschodnie, 3300 subskrypcji) - (Freies Ostpreussen), Freies Westpreussen (Wolne Prusy Zachodnie, w tym Danzig - Gdańsk, 735 subskrypcji) (Freies Westpreussen), Freies Sudetenland (Wolne Sudety, przedmiot sporu III Rzeszy z Czechosłowacją przed II wojną światowa, 659 subskrypcji) - (Freies Sudetenland), Freies OstBrandenburg (Wolna Wschodnia Branderburgia, czyli polskie województwa zachodnie, dawniej Ziemie Odzyskane wraz z Wrocławiem, 306 subskrypcji) - (Freies

6 Oryginał: „veröffentlicht In Niederschlesien wurden und werden deutsche Friedhöfe nicht nur vernachlässigt, sondern sogar gezielt geschändet. Die Lügenpresse und die politische Kanaille halten diese Zustände in grenzenloser Niedertracht vor dem deutschen Volk geheim - Von diesem wiederum ist aufgrund seiner Entwurzelung allerdings auch nicht viel zu erwarten. Ebensowenig vom polnischen Staat, der nichts gegen diese Zustände unternimmt. Ein erschütterndes Zeugnis des desolaten Zustands, in dem sich Deutschland befindet." (Reconqui). 
Ost Brandenburg). Użytkownik o inicjałach AR napisał w komentarzu do dyskusji o Wolnej Wschodniej Branderburgii: „Ostbrandenburg ist und bleibt deutsch! (Wschodnia Branderburgia jest i pozostanie niemiecka)" (Freies Ost Brandenburg Discussion). Cała seria filmów dotycząca dawnych ziem znajdujących się pod niemieckim lub pruskim panowaniem ma wspólny element, który je łączy. Jest to słowo: Freies - wolny. Odczytujemy to jako wskazówkę, że w rozumieniu uczestników tego dyskursu tereny te są obecnie okupowane przez Polskę, Rosję i Czechy, a rozstrzygnięcia geopolityczne dokonane po II wojnie światowej należy zmienić, przywracając status quo z okresu świetności Rzeszy. Towarzyszący temu przekaz, który przebija się przez dyskusję, dotyczy, w naszym mniemaniu, rzekomej martyrologii i tzw. problemu „wypędzeń" Niemców.

Zaprezentowane wyżej kanały, zawierające filmy o jednoznacznie rewanżystowskiej i neonazistowskiej wymowie, są amplifikowane do mediów społecznościowych, gdzie rozprzestrzeniają się wiralowo oraz infekują świadomość pokolenia Y i Z:

- Facebook: https://www.facebook.com/ReconquistaG...,

- Twitter: https://twitter.com/ReconquistaGer,

- Google+: https://plus.google.com/+ReconquistaG...

Największą uwagę jednak skupiają na sobie filmy propagandowe dotyczące Waffen SS. Ta zbrodnicza formacja znajduje dzisiaj znaczące audytorium $\mathrm{w}$ mediach społecznościowych. W serwisie YT odnaleziono także kanał w języku polskim gloryfikujący tę formację (Gladiatorzy II Wojny Światowej - Waffen SS). W komentarzach pod innym filmem: The Einsatzgruppen, użytkownik o inicjałach TD napisał: „FOREVER SS”, a FD: „HEIL unserer Einsatz gruppe Ohlendorff, dem Graalshueter der SS!" (The Einsatzgruppen). Liczby wyświetleń, polubień i udostępnień, a także komentarzy dotyczących tej tematyki idą w dziesiątki, a nawet setki tysięcy. Trudno w warunkach jednego artykułu uchwycić nawet fragment tej debaty oraz jej zasięgu.

\section{NEONAZIZM ON I OFFLINE}

W Design Museum Den Bosch w Holandii funkcjonuje od niedawna wystawa zatytułowana „Design Trzeciej Rzeszy” (Protest tegen nazikunst). Timo de Rijk, autor wystawy, zgromadził tam eksponaty, 
Zjawisko zahibernowanej propagandy politycznej w nowych mediach

które stanowiły jądro propagandy Josepha Goebbelsa. Obok Volkswagena "Garbusa" (konstrukcja powstała w wyniku inicjatywy Adolfa Hitlera) i swastyki, można tam zobaczyć:

historyczne filmy i fotografie, [które] pokazują nazistowskie przemarsze czy Olimpiadę z 1936 roku. Na ekranach wyświetlane są filmy Leni Riefenstahl, która doskonale wiedziała, jak sugestywnie pokazać nazistowską ideologię, chociażby w swoim propagandowym filmie Triumf woli o zjeździe NSDAP w 1934 roku w Norymberdze (Dege, 2019).

Mimo że motywacja twórców wystawy jest usprawiedliwiona argumentami o charakterze kulturowym, to spotkała się z ostrą reakcją antyfaszystów z różnych środowisk. Dla przykładu:

Związek Holenderskich Antyfaszystów (AFVN) uznał wystawę za „prowokacyjną" i wezwał władze miasta do „interwencji”. Kierownik Izraelskiego Centrum Informacji i Dokumentacji w Hadze Hanna Luden określiła projekt wystawy jako „ryzykowne posunięcie” (Dege, 2019).

Interweniowała także rosyjska telewizja RT, alarmując międzynarodową opinię publiczną o problemie odradzania się nazizmu w Europie.

Czy rzeczywiście jest się czego obawiać? W czerwcu 2019 roku w Kassel w Hesji zamordowano chadeckiego polityka Waltera Lubcke. Prokuratura wiąże to wydarzenie z działalnością skrajnej prawicy. Raporty kontrwywiadowcze wskazuja że obecnie w Niemczech działa około 24 tysięcy neonazistów, co w stosunku do ogólnej liczby obywateli naszego zachodniego sąsiada stanowi minimalny udział procentowy (Strzałkowski, 2019). Ta niewielka grupa działaczy jest jednak bardzo aktywna ${ }^{7}$, a co gorsza przywodzi nam na pamięć wydarzenia, które przeszły do historii Niemiec jako pucz monachijski (czy też pucz piwiarniany) (Monachijski pucz).

7 „W sierpniu ubiegłego roku około pięciuset neonazistów maszerowało w Berlinie z okazji rocznicy śmierci Rudolfa Hessa, jednego z najbliższych współpracowników Adolfa Hitlera. W 2016 roku w Niemczech miało miejsce 466 demonstracji neonazistów i 223 koncerty ich muzyki - wynika z danych niemieckiego MSW" (Neonaziści w Niemczech szaleja). 
Po zamachu dokonanym w Christchurch w Nowej Zelandii w Europie rozpętała się dyskusja na temat obecności nazistowskiej propagandy w postaci podcastów, audiobooków i filmów w serwisie YouTube. Platforma dość szybko podjęła decyzję o demonetyzacji tych materiałów i usuwaniu komentarzy, lecz nie zdecydowała o ich całkowitym usunięciu z serwisu (Makuch, 2019). W tym czasie: "YouTube wyłączył i usunął niektóre neonazistowskie kanały, ale wiele treści wciąż jest dostępnych online. Na przykład w marcu 2018 roku platforma usunęła kanał grupy «Atomwaffen Division», która publikowała filmy wzywające do «wojny rasowej»" (Makuch, 2019). W jednym z filmów grupa apelowała do użytkowników o udostępnienie ich treści w mediach społecznościowych: „rozpowszechniaj i odzwierciedlaj naszą pracę w różnych mediach społecznościowych: YouTube, Facebook, Twitter itp. (...) Dołącz do lokalnych nazistów! (Makuch, 2019).

Zdaniem Christopha Ulbricha:

YouTube jest pełen nazistowskiej propagandy. Dyskusje na temat mowy nienawiści i brutalnych filmów w Internecie rozprzestrzeniły się szeroko w ostatnich miesiącach. Facebook zareagował po długim wahaniu. Prokuratura coraz częściej rozpoczyna dochodzenia w sprawie „podżegania” na Facebooku. (...) Przyjrzeliśmy się YouTube i odkryliśmy wiele propagandy faszystowskiej (...), z zaskakująco dużą liczbą kliknięć (Ulbrich, 2017).

Według tego samego autora, na platformie YouTube funkcjonuje $\mathrm{w}$ postaci zahibernowanej skandalizująca, neonazistowska grupa muzyczna - „Landser". W ich repertuarze znajdują się takie „utwory" jak Nigger, Rassenkrieg czy Polacken Tango. Mimo że grupa pod wpływem wyroków sądowych rozpadła się, a w zasadzie dokonała rebrandingu na „Lunikoff”, ich „popularność” w mediach społecznościowych jest wciąż ogromna. Polacken Tango jest niedostępny w Polsce, ale mogą go oglądać Niemcy czy obywatele innych krajów (Jadowska, 2011). Refren tej piosenki wart jest zacytowania w kontekście tematu podjętego w publikacji. Brzmi on następująco:

Kiedy polska flota zatonie pod Gdańskiem. I niemiecka piosenka zabrzmi w Malborku. Wtedy do Wrocławia wkroczy Wehrmacht z oddziałami pancernymi. I wtedy w końcu Wschodnie Niemcy wrócą z powrotem do ojczyzny (Jadowska, 2011). 
Zjawisko zahibernowanej propagandy politycznej w nowych mediach

Podobnie wybrzmiewają teksty zespołów „Sturmwehr” czy „Perpetrator's Voice", heroizujące dokonania Großvater Adolf Hitler.

\section{ZAKOŃCZENIE}

Analiza komentarzy zamieszczanych pod filmami propagandowymi z okresu III Rzeszy w serwisie YouTube oraz procesu amplifikacji tych treści w mediach społecznościowych, ponad wszelką wątpliwość pozwala potwierdzić tezę o silnym ich oddziaływaniu na te grupy użytkowników mediów społecznościowych, które współcześnie kontestują ideologię faszystowską. Treści te przetrwały okres niesprzyjający $\mathrm{w}$ postaci uśpionej i obecnie stają się coraz dostępniejsze w sieci, trafiając do środowisk nieprzygotowanych do ich krytycznego odbioru.

Rezultatem zaprezentowanych wyżej badań jest konstatacja, że w przestrzeni wirtualnej dostrzegamy swoisty coming out zwolenników tej ideologii, którzy gromadzą się zarówno w postaci wspólnot on -jak i offlinowych. Spostrzeżenia te nawiązują w swojej wymowie do teorii spirali milczenia sformułowanej przez Elizabeth Noelle-Neumann. Ponadto należy stwierdzić, że analiza popularności tych materiałów pozwala postawić tezę, iż obrazy Leni Riefenstahl nie cieszą się wśród użytkowników YT popularnościa, są być może nazbyt pompatyczne, natomiast swoisty renesans przeżywają filmy na temat Waffen SS. Dostrzegalny jest również nieuzasadniony proces retorycznej heroizacji tych formacji w opiniach części użytkowników. Nieuzasadniony dlatego, że organizacja ta uznana została za zbrodnicza, a ponadto $\mathrm{w}$ trakcie działań wojennych żołnierze Wehrmachtu oraz formacji SS otrzymywali Pervitin, czyli metaamfetaminę, dla zwiększenia wytrzymałości, siły i odwagi (Dietrich-Muszalska, 2012, 187-192). Informacja ta burzy zatem mit o heroizmie niemieckiego żołnierza.

\section{BiBLIOGRAFIA}

Aylett, G. (2008). Hitler's Radio. Pozyskano z https://www.transdiffusion. org/2008/01/07/hitlers_radio

Bucher, P. (1986). Goebbels und die Deutsche Wochenschau. Nationalsozialistische Filmpropaganda im Zweiten Weltkrieg 1939-1945, Militärgeschichtliche Mitteilungen, 15. 
Dege, S. (2019). Garbus i nazistowskie bibeloty: "Design Trzeciej Rzeszy" w muzeum. Pozyskano z https://www.dw.com/pl/garbus-i-nazistowskie-bibeloty-design-trzeciej-rzeszy-w-muzeum/a-50339712

Die Deutsche Wochenschau (Nr. 715 | 17.05.1944). Pozyskano z https:// www.youtube.com/watch?v=BN4ZHl-GDDY

Die Oberschlesier - Tatsachen uber Oberschlesien. Pozyskano z https://www. youtube.com/watch?v=GW0w6oVJ9ks

Dietrich-Muszalska, A. (2012). Pervityna „krystaliczna metamfetamina" - nowe zagrożenie na polskiej scenie narkotykowej, Psychiatria i Psychologia Kliniczna, 12 (3).

Downing, T. (2012). Pozyskano z The Olympics on Film. Pozyskano z https://www.historytoday.com/archive/olympics-film

Freies Ostpreussen. Pozyskano z https://www.youtube.com/user/ FreiesOstpreussen

Freies Pommern. Pozyskano z https://www.youtube.com/user/ FREIESPOMMERN1

Freies Schlesien. Pozyskano z https://www.youtube.com/user/ FreiesSchlesien1

Freies Sudetenland. Pozyskano z https://www.youtube.com/user/ FreiesSudetenland

Freies Westpreussen. Pozyskano z https://www.youtube.com/user/ FreiesWestpreussen

Freies Ost Brandenburg Discussion. Pozyskano z https://www.youtube. com/user/FreiesOstBrandenburg/discussion

Freies Ost Brandenburg. Pozyskano https://www.youtube.com/user/ FreiesOstBrandenburg.

German propaganda Archive (1998). Pozyskano z https://research.calvin. edu/german-propaganda-archive/goeb36.htm

Gladiatorzy II Wojny Światowej - Waffen SS. Pozyskano z https://www. youtube.com/watch?v=0SPoukzueO4

Halbrook, S. (2015). Szwajcaria i naziści. Jak alpejska republika przetrwała w cieniu III Rzeszy. Wrocław: Wydawnictwo Dolnośląskie.

https://www.youtube.com/watch?v=-losEBtmq68

Instynkty człowieka - trzy podstawowe instynkty. Pozyskano z http://womanadvice.pl/instynkty-człowieka-trzy-podstawowe-instynkty

Jadowska,L.(2011).ZespółLandsergroziwejściem WehrmachtudoWrocławia.Klip Polacken Tangojestdostepnywsieci.Pozyskanozhttps://wroclaw.naszemiasto.pl/zespol-landser-grozi-wejsciem-wehrmachtu-do-wroclawia-klip/ ar/c13-3192369

Lemmons, R. (2015). Goebbels and Der Angriff. Lexington: The University Press of Kentucky.

Longerich, P. (2015). Goebbels: A Biography. New York: Random House. 
Zjawisko zahibernowanej propagandy politycznej w nowych mediach

Makuch, B. (2019). YouTube Decides to Leave Neo-Nazi Propaganda Online. Pozyskano z https://www.vice.com/en_us/article/mbzzzx/ youtube-decides-to-leave-neo-nazi-propaganda-online

Model wszechmocy propagandy (2016). Pozyskano z https://docer.pl/doc/ c018

Monachijski pucz. Pozyskano z https://encyklopedia.pwn.pl/haslo/monachijski-pucz;3942904.html

Neonaziści w Niemczech szaleją. Ale to Polsce próbuje się przyprawiać gębę. Pozyskano z https://niezalezna.pl/215248-neonazisci-w-niemczech-szaleja-ale-to-polsce-probuje-przyprawiac-sie-gebe

Oberschlesien - Unvergessene Heimat im Osten. Pozyskano https://www. youtube.com/watch? $\mathrm{v}=$ mcxIgx_0I8E

Płuciennik, J. (2013). Pomiar aktywności w mediach społecznościowych wyzwanie współczesnych badań marketingowych. Marketing instytucji naukowych i badawczych, 8 (2).

Protest tegen nazi-kunst in Design Museum Den Bosch: 'Geen nazi-propaganda in museum' (2019). Pozyskano z https://www.omroepbrabant.nl/ nieuws/3040719/Protest-tegen-nazi-kunst-in-Design-Museum-Den-Bosch-Geen-nazi-propaganda-in-museum

Reconqui. Pozyskano z https://www.youtube.com/user/Reconqui.

Strzałkowski, M.(2019). Niemcy: Ponad24 tys. neonazistów. Liczba rośniez roku na rok. Pozyskanozhttps://www.euractiv.pl/section/demokracja/news/ niemcy-rosnie-liczba-sympatykow-organizacji-neonazistowskich/

The Einsatzgruppen. Pozyskano z https://www.youtube.com/watch?v $=$ RT276DHbOzI.

Tye, L. (1998). The Father of Spin: Edward L. Bernays and the Birth of Public Relations. New York: Crown Publishers.

Ulbrich Ch., (2017). YouTube ist voll von Nazi Propaganda. Pozyskano z https://www.semiosis.at/2017/01/05/youtube-ist-voll-von -nazi-propaganda/.

Winkel, R.V. (2004). Nazi newsreels in Europe, 1939-1945: the many faces of Ufa's foreign weekly newsreel (Auslandstonwoche) versus the German weekly newsreel (Deutsche Wochenschau). Historical Journal of Film, Radio and Television, 24.

YouTube dla prasy. Pozyskano z https://www.youtube.com/intl/pl/about/ press/.

\section{Copyright and License}

This article is published under the terms of the Creative Commons Attribution - NoDerivs (CC BY- ND 4.0) License http://creativecommons.org/licenses/by-nd/4.0/ 